\title{
Determinants of first prescription of hormone replacement therapy. A follow-up study among 1689 women aged 45-60 years
}

\author{
F.P.M.J. Groeneveld*a , F.P. Bareman ${ }^{a}$, R. Barentsen ${ }^{\text {d, H.J. Dokter }}{ }^{\mathrm{a}}$, \\ A.C. Drogendijk ${ }^{b}$, A.W. Hoes ${ }^{a, c}$ \\ ${ }^{\mathrm{a}}$ Department of General Practice, ${ }^{\mathrm{b}}$ Department of Obstetrics and Gynaecology, ${ }^{\mathrm{c} D e p a r t m e n t}$ of Epidemiology and Biostatistics. \\ Erasmus University Rotterdam, Mathenesserlaan 264a, 3021 HR Rotterdam, The Netherlands \\ 'Department of Obstetrics and Gynaecology, Elkerliek Hospital, Helmond, The Netherlands
}

Received 22 November 1993; revision received 21 March 1994; accepted 25 March 1994

\begin{abstract}
The aim of the present study was to ascertain the cumulative incidence of first hormone replacement therapy (HRT) and the factors that predict its prescription. In a general population 1689 women were followed for 9 months in order to trace first HRT prescriptions. Determinants (well-being, attitude towards menopause, menopausal status and another 9 variables) were measured by means of a questionnaire. Data analyses were performed for all women and for women with or without typical climacteric complaints. The cumulative 9 month incidence of HRT was 6.2\%. For women without typical complaints a lower level of well-being (odds ratio $5.5 ; 95 \% \mathrm{CI} 1.9-15.5$ ) and the former use of the contraceptive pill (odds ratio $4.6 ; 95 \% \mathrm{CI} 1.0-20.5$ ) were independently associated with HRT prescription. For women with typical complaints a positive attitude towards 'menopause should be treated' (odds ratio $3.8 ; 95 \%$ CI 1.8-8.0) was a determinant of HRT prescription. The cumulative incidence of HRT prescription is high, but from additional data it is apparent that within a period of 1 year and 9 months the majority of women stop taking HRT. For women without typical complaints, physicians prescribe HRT five times more often to those with a lower level of well-being. For women with typical complaints the physician's prescription is primarily related to the woman's attitude towards (medical) treatment of the menopause.
\end{abstract}

Keywords: Determinants; HRT; Well-being; Attitude towards menopause; Typical complaints; Climacteric

\section{Introduction}

Hormone replacement therapy has been available for about 40 years. The first placebo controlled efficacy study was reported in 1950 [1]. Since

\footnotetext{
* Corresponding author.
}

then, many other studies have argued the benefits of HRT. They have provided evidence that HRT is profitable for women in the climacteric years with vasomotor complaints, vaginal dryness and disturbances in menstruation pattern (the so-called typical complaints). Furthermore, HRT is probably useful in the prevention of postmenopausal 
bone loss [2-4] and death from coronary heart disease [5-7]. Nevertheless, several authors report a low prevalence of HRT use [8,9].

Several factors that influence the decision to use HRT have been reported in the literature. The regular withdrawal bleeding as a result of the cyclic oestrogen/progestagen therapy is often experienced as unacceptable $[10,11]$. Also, fear of cancer seems to be an important reason to refrain from HRT [12]. In contrast, women who are interested in health promotion and disease prevention measures are more willing to take estrogens [13]. Furthermore, a higher rate of medical consultations, a belief in the efficacy of medical treatment (especially hormonal treatment), experience of hot flushes, women's overall experience of menopause, parity, education and smoking behaviour may influence the use of HRT [14-15].

Next to these factors which are related to the women, doctor-related factors may be equally important, e.g. the judgment of the physicians concerning HRT leads to considerable differences in prescribing behaviour and a clear inter-doctor variability has been documented $[16,17]$.

The aim of this study was to estimate the cumulative incidence of first HRT prescription and the influence of the woman's well-being, attitude towards menopause, menopausal status and other variables on first HRT prescription in a population at large during a 9 month follow-up period. For women as well as their doctors the so-called typical complaints are probably the major indication for HRT $[8,18,19]$. Therefore, the incidence and determinants of HRT were studied among women with and without these complaints.

\section{Subjects and methods}

\subsection{Recruitment}

This study is part of a larger study aimed at assessing the relationships between climacteric, well-being, women's attitude towards menopause and medical attention. The methods applied to measure well-being and attitude towards menopause have been reported in detail elsewhere $[20,21]$. In short, from the municipal authorities of Krimpen aan den Ijssel, a commuter suburb of Rotterdam with approximately 28000 inhabitants, names and addresses of all 2729 women aged between 45-60 years were obtained. In May 1990 they were sent a questionnaire; 1947 women responded (response $71.3 \%$ ). A random sample $(N=55)$ was taken of the non-respondents in order to evaluate the representativity of the respondent group. They were approached by telephone and 52 participated (response 95\%). The comparison between respondents and nonrespondents revealed no statistically significant differences in age, menopausal status, hysterectomy, estrogen therapy, level of education, work outside the home or medical attention.

To measure the cumulative incidence of first HRT prescriptions, assistance was given by the two pharmacies in Krimpen aan den Ijssel. Both pharmacies are computerized. Of the women who returned the questionnaire, the 220 women (prevalence $11.5 \%$ ) who had used estrogen therapy within 6 months preceding answering the questionnaire and the 7 women who used progestagens without estrogens were excluded. A further 31 women could not be traced in the pharmacies' database. The remaining 1689 women were registered at the pharmacies, included in the study and followed for a period of 9 months. The followup period lasted from July 1st 1990 until April 1st 1991.

The study received approval from the Medical Ethical Committee of the Erasmus University and Academic Hospital Dijkzigt in Rotterdam.

\subsection{Measurements}

General well-being was measured by two validated inventories: the 'Inventory of Subjective Health' (ISH) and the 'Sickness Impact Profile' (SIP). The ISH has proven to be a sensitive instrument to detect health problems [22-24]. The ISH includes 49 items, concerning the experience in the past 2 weeks, for example; pains in the chest, trembling hands, headache, sneezing and loss of appetite. On every item the respondent is asked whether she has experienced this during the last 2 weeks. All items must be answered with either 'yes' or 'no'. The maximum score is 49. The SIP was developed in the United States as a behaviourally based measure of the impact of sickness [25]. In this study, the Dutch validated version has been 
Table 1

Cumulative incidence within 9 months of first hormone replacement therapy among 1689 women aged 45-60 years (\%)

\begin{tabular}{|c|c|c|c|c|c|c|}
\hline & All women & $P^{a}$ & $\begin{array}{l}\text { Without } \\
\text { typical } \\
\text { complaints }\end{array}$ & $P$ & $\begin{array}{l}\text { With } \\
\text { typical } \\
\text { complaints }\end{array}$ & $P$ \\
\hline Total $(n)$ & $6.2(104)$ & & $4.4(37)$ & & $8.0(67)$ & \\
\hline \multicolumn{7}{|l|}{ Measures of well-being ${ }^{b}$} \\
\hline $\begin{array}{l}\text { ISH }(1251) \\
\text { below median } \\
\text { above median }\end{array}$ & $\begin{array}{l}4.4 \\
9.0\end{array}$ & 0.001 & $\begin{array}{l}2.9 \\
8.6\end{array}$ & 0.002 & $\begin{array}{l}6.7 \\
9.2\end{array}$ & 0.260 \\
\hline $\begin{array}{l}\text { SIP - social interaction (1335) } \\
\text { below median } \\
\text { above median }\end{array}$ & $\begin{array}{l}5.5 \\
6.8\end{array}$ & 0.316 & $\begin{array}{l}3.9 \\
4.5\end{array}$ & 0.701 & $\begin{array}{l}7.7 \\
8.5\end{array}$ & 0.700 \\
\hline $\begin{array}{l}\text { SIP - emotions, feelings and sensations (1509) } \\
\text { below median } \\
\text { above median }\end{array}$ & $\begin{array}{l}5.1 \\
8.8\end{array}$ & 0.005 & $\begin{array}{l}3.9 \\
7.0\end{array}$ & 0.069 & $\begin{array}{l}6.5 \\
9.9\end{array}$ & 0.082 \\
\hline $\begin{array}{l}\text { SIP - intellectual functioning (1454) } \\
\text { below median } \\
\text { above median }\end{array}$ & $\begin{array}{l}5.9 \\
6.7\end{array}$ & 0.518 & $\begin{array}{l}3.9 \\
4.5\end{array}$ & 0.668 & $\begin{array}{l}8.2 \\
8.2\end{array}$ & 0.974 \\
\hline \multicolumn{7}{|l|}{ Attitude measurements } \\
\hline $\begin{array}{l}\text { Menopause is disadvantageous (1294) } \\
\text { more positive } \\
\text { more negative }\end{array}$ & $\begin{array}{l}6.9 \\
5.3\end{array}$ & 0.217 & $\begin{array}{l}5.2 \\
3.5\end{array}$ & 0.308 & $\begin{array}{l}8.2 \\
7.3\end{array}$ & 0.674 \\
\hline $\begin{array}{l}\text { Menopause is advantageous (1299) } \\
\text { more positive } \\
\text { more negative }\end{array}$ & $\begin{array}{l}5.1 \\
7.0\end{array}$ & 0.168 & $\begin{array}{l}3.6 \\
4.7\end{array}$ & 0.510 & $\begin{array}{l}6.5 \\
9.1\end{array}$ & 0.221 \\
\hline $\begin{array}{l}\text { Menopause should be treated (1424) } \\
\text { more positive } \\
\text { more negative }\end{array}$ & $\begin{array}{l}8.5 \\
3.6\end{array}$ & 0.000 & $\begin{array}{l}4.7 \\
2.8\end{array}$ & 0.182 & $\begin{array}{r}12.1 \\
4.4\end{array}$ & 0.000 \\
\hline \multicolumn{7}{|l|}{ Menopausal status } \\
\hline $\begin{array}{l}\text { Menopausal status according to last } \\
\text { menstrual bleeding (1332) } \\
\text { premenopausal } \\
\text { perimenopausal } \\
\text { postmenopausal }\end{array}$ & $\begin{array}{l}7.0 \\
7.3 \\
5.5\end{array}$ & 0.401 & $\begin{array}{l}6.1 \\
6.9 \\
3.0\end{array}$ & 0.071 & $\begin{array}{l}9.3 \\
7.7 \\
7.6\end{array}$ & 0.877 \\
\hline $\begin{array}{l}\text { Menopausal status according to the women } \\
\text { themselves (1594) } \\
\text { premenopausal } \\
\text { perimenopausal } \\
\text { postmenopausal }\end{array}$ & $\begin{array}{l}7.0 \\
7.1 \\
3.3\end{array}$ & 0.027 & $\begin{array}{l}5.0 \\
5.5 \\
2.1\end{array}$ & 0.128 & $\begin{array}{r}14.8 \\
8.0 \\
5.2\end{array}$ & 0.065 \\
\hline \multicolumn{7}{|l|}{ Other variables } \\
\hline $\begin{array}{l}\text { Age-group, years }(1641) \\
45-50 \\
51-55 \\
56-60\end{array}$ & $\begin{array}{l}9.2 \\
5.0 \\
3.5\end{array}$ & 0.000 & $\begin{array}{l}7.1 \\
3.1 \\
1.8\end{array}$ & 0.004 & $\begin{array}{r}11.7 \\
6.5 \\
5.3\end{array}$ & 0.014 \\
\hline $\begin{array}{l}\text { Education (1651) } \\
\text { low } \\
\text { middle } \\
\text { high }\end{array}$ & $\begin{array}{l}3.5 \\
7.0 \\
6.0\end{array}$ & 0.089 & $\begin{array}{l}3.9 \\
4.6 \\
5.0\end{array}$ & 0.910 & $\begin{array}{l}3.0 \\
9.3 \\
7.2\end{array}$ & 0.055 \\
\hline
\end{tabular}


Table 1

Cumulative incidence within 9 months of first hormone replacement therapy among 1689 women aged 45-60 years (\%)

\begin{tabular}{|c|c|c|c|c|c|c|}
\hline & All women & $p^{a}$ & $\begin{array}{l}\text { Without } \\
\text { typical } \\
\text { complaints }\end{array}$ & $P$ & $\begin{array}{l}\text { With } \\
\text { typical } \\
\text { complaints }\end{array}$ & $P$ \\
\hline Body mass index, $\mathrm{Kg} / \mathrm{m}^{2}(1585)$ & & 0.681 & & 0.751 & & 0.452 \\
\hline below median & 5.9 & & 4.8 & & 7.0 & \\
\hline above median & 6.4 & & 4.3 & & 8.5 & \\
\hline Smoking behaviour (1619) & & 0.004 & & 0.092 & & 0.039 \\
\hline never & 5.8 & & 4.2 & & 7.5 & \\
\hline $1-15 /$ day & 4.4 & & 1.6 & & 7.0 & \\
\hline$>15 /$ day & 12.6 & & 8.5 & & 15.8 & \\
\hline Contraceptive pill (1643) & & 0.000 & & 0.037 & & 0.002 \\
\hline never used & 3.2 & & 2.6 & & 4.0 & \\
\hline formerly used & 8.0 & & 5.7 & & 10.2 & \\
\hline Parity (1689) & & 0.714 & & 0.267 & & 0.867 \\
\hline no children & 5.0 & & 1.8 & & 7.8 & \\
\hline one child & 7.5 & & 5.4 & & 9.2 & \\
\hline two children & 6.2 & & 3.6 & & 8.7 & \\
\hline three children & 6.8 & & 7.0 & & 6.6 & \\
\hline$\geq$ four children & 4.7 & & 3.2 & & 6.7 & \\
\hline Hysterectomy (1659) & & 0.008 & & 0.109 & & 0.051 \\
\hline no & 5.5 & & 4.0 & & 6.8 & \\
\hline yes, unilateral oophorectomy & 11.3 & & 9.3 & & 12.9 & \\
\hline yes, bilateral oophorectomy & 9.3 & & 4.3 & & 15.0 & \\
\hline Medical attention last 2 weeks ( 1654 ) & & 0.932 & & 0.850 & & 0.725 \\
\hline no & 6.3 & & 4.4 & & 8.3 & \\
\hline yes & 6.4 & & 4.7 & & 7.7 & \\
\hline General practice (1641) & & 0.036 & & 0.088 & & 0.239 \\
\hline A & 3.3 & & 1.1 & & 5.4 & \\
\hline B & 3.5 & & 2.1 & & 4.8 & \\
\hline $\mathrm{C}$ & 8.1 & & 6.1 & & 9.8 & \\
\hline D & 6.5 & & 4.0 & & 9.7 & \\
\hline $\mathbf{E}$ & 6.7 & & 7.1 & & 6.3 & \\
\hline
\end{tabular}

${ }^{a} P$-value based on the $\chi$-test.

bISH, Inventory of Subjective Health; SIP, Sickness Impact Profile.

used [26]. Both SIP overall scores and SIP category scores can discriminate between sub-samples of respondents. We have chosen three category scores which measure psycho-social impact on well-being: emotions, feelings and sensations $(9$ items), social interaction (18 items) and intellectual functioning (10 items). All items are rated on a scaling factor. This scaling permits the calculation of three SIP percent category scores. A percentage of 100 means maximal impairment on the corresponding category score.

Three attitude clusters towards menopause were distinguished: two clusters encompass items reflecting the idea that 'menopause is advantageous' and 'menopause is disadvantageous' and one cluster encompasses items reflecting the idea that 'menopause should be treated (medically)' [21]. The women were asked to rate their opinion on all items on a scale ranging from 1 (totally agree) to 5 (totally disagree). Mean scores per cluster were computed.

To ascertain menopausal status according to last menstrual bleeding, women were classified into pre-, peri- and postmenopausal according to menstrual history. Premenopausal women were women having a regular menstruation pattern in the preceding 12 months. Women were considered perimenopausal when irregular cycles or amenor- 
rhoa had developed in the 12 months prior to the questionnaire. Women were classified as postmenopausal if last menstrual bleeding occurred at least 12 months ago. Women who had undergone hysterectomy were categorized as a separate group.

The women were also asked to rate their climacteric phase themselves by choosing one of the following five categories: 'I have not reached the menopause' (classified as premenopausal), 'I have just reached the menopause', 'I am in the middle of the menopause', 'I have reached the end of the menopause' (all three categories classified as perimenopausal), 'I reached the menopause long ago'(classified as postmenopausal).

The methods used to measure the other potential determinants of the initial HRT such as body mass index, smoking behaviour, parity, age, general practice are shown in Table 1.

Women were categorized as having typical (climacteric) complaints when they reported one or more of the following symptoms on the questionnaire: hot flushes, severe sweating, vaginal dryness or menstruation disturbances. The presence of severe sweating and vaginal dryness were assessed by using both a closed and an open question, whereas the presence of hot flushes and menstruation disturbances were assessed using an open question only. The closed questions were incorporated in a symptom checklist, where the women could encircle either yes or no when they had regularly experienced a symptom during the last two weeks. In the open question the women could indicate any symptom they experienced during the last 4 weeks.

\subsection{Analysis}

The cumulative incidence of first HRT prescriptions during 9 months was computed. Linear variables were dichotomized around the median. The association between possible determinants and first HRT prescriptions was studied by means of the $\chi^{2}$-test. Determinants that were associated with first HRT prescription on a $P<0.10$ level were then included in a logistic regression analysis to ascertain the relative contributions. For all ordinal and nominal variables dummy variables were constructed to detect non-linear effects. The back- ward stepwise procedure was used retaining only variables that contributed on a $P<0.10$ level to the prediction of first HRT prescriptions.

As the relationships between the determinants and first HRT prescriptions may be modified by the presence of typical (climacteric) complaints, subgroup analyses were performed for the women without and women with typical complaints.

\section{Results}

The 9 month cumulative incidence of first HRT prescriptions was $6.2 \%$ (104 women). This equals a 1 year cumulative incidence of $8.2 \%$. The incidence of first HRT prescriptions among women without typical complaints at baseline was $4.4 \%$, whereas the incidence for women with typical complaints was $8.0 \%$.

\subsection{Determinants of first HRT prescriptions for all women}

Table 1 shows the relationship between first HRT prescriptions and possible determinants. Only statistically significant associations are reported below. Two measures of well-being predicted first HRT prescriptions: women below the median of the ISH - i.e. the half of women that feel relatively well - had an incidence of $4.4 \%$ whereas the women above the median of the ISH had an incidence of $9.0 \%$. For the SIP - emotions, feelings and sensations, these figures were $5.1 \%$ and $8.8 \%$, respectively. From the attitude measurements, the cluster 'menopause should be treated (medically)' was related to HRT prescription. Women who thought more positively had an incidence of $8.5 \%$, whereas the other women had an incidence of $3.6 \%$. Only the menopausal status according to the women themselves was associated with first HRT. Of the premenopausal women $7.0 \%$, of the perimenopausal women $7.1 \%$ and of the postmenopausal women $3.3 \%$ started using HRT within the 9 months.

Furthermore, women who were younger, women who smoked more than 15 cigarettes per day, women who formerly used the contraceptive pill and women who were hysterectomized were more often prescribed HRT. Women who were enlisted in general practice $\mathrm{C}$ had the highest inci- 
Table 2

Significant determinants from the multivariate logistic regression analysis of first hormone replacement therapy prescription among 1689 women aged $45-60$ years

\begin{tabular}{|c|c|c|c|c|c|c|}
\hline \multirow[t]{2}{*}{$\begin{array}{l}\text { Variable contained in the } \\
\text { regression model }\end{array}$} & \multicolumn{2}{|l|}{ All women } & \multicolumn{2}{|c|}{$\begin{array}{l}\text { Women without } \\
\text { typical complaints }\end{array}$} & \multicolumn{2}{|c|}{$\begin{array}{l}\text { Women with } \\
\text { typical complaints }\end{array}$} \\
\hline & Odds ratio & $95 \% \mathrm{CI}^{\mathrm{a}}$ & Odds ratio & $95 \% \mathrm{Cl}$ & Odds ratio & $95 \% \mathrm{CI}$ \\
\hline $\begin{array}{l}\text { Variance accounted for by the } \\
\text { variables }\end{array}$ & $3.8 \%$ & & $4.0 \%$ & & $2.8 \%$ & \\
\hline $\begin{array}{l}\text { Typical complaints } \\
\text { not present } \\
\text { present }\end{array}$ & $\begin{array}{l}1.0 \\
1.7\end{array}$ & $(0.9 ; 3.0)$ & - & & - & \\
\hline ISH $^{\mathbf{b}}$ & & & & & - & \\
\hline $\begin{array}{l}\text { below median } \\
\text { above median }\end{array}$ & $\begin{array}{l}1.0 \\
2.0\end{array}$ & $(1.1 ; 3.6)$ & $\begin{array}{l}1.0 \\
5.5\end{array}$ & $(1.9 ; 15.5)$ & & \\
\hline $\begin{array}{l}\text { Menopause should be treated } \\
\text { more negatively }\end{array}$ & 1.0 & & - & & 1.0 & \\
\hline more positively & 2.7 & $(1.5 ; 4.9)$ & & & 3.8 & $(1.8 ; 8.0)$ \\
\hline $\begin{array}{l}\text { Smoking behaviour } \\
\text { never } \\
1-15 \text { cigarettes } \\
>15 \text { cigarettes }\end{array}$ & $\begin{array}{l}1.0 \\
1.0 \\
2.2\end{array}$ & $\begin{array}{l}(0.4 ; 2.2) \\
(1.1 ; 4.6)\end{array}$ & - & & - & \\
\hline $\begin{array}{l}\text { Contraceptive pill } \\
\text { never used } \\
\text { ever used }\end{array}$ & $\begin{array}{l}1.0 \\
2.3\end{array}$ & $(1.1 ; 4.6)$ & $\begin{array}{l}1.0 \\
4.6\end{array}$ & $(1.0 ; 20.5)$ & - & \\
\hline
\end{tabular}

$95 \%$ CI, 95\% confidence interval.

'ISH, Inventory of Subjective Health.

dence of first HRT use (8.1\%), while women in general practice $\mathbf{A}$ had the lowest 9 month prescription rate $(3.3 \%)$.

The results of the multivariate logistic regression analysis are shown in Table 2 . Within the 9 months of the study, women with typical complaints were prescribed HRT 1.7 times $(95 \%$ CI $0.9 ; 3.0)$ more often than women without these complaints. The likelihood of HRT prescription for women above the median of the ISH was $2.0(95 \%$ CI $1.1 ; 3.6)$ times higher than for women below the median. For the women who thought more positively about the attitude cluster 'menopause should be treated' the odds ratio equalled 2.7 (95\% CI 1.5 ; 4.9) compared to the women who thought more negatively. Women who smoked more than 15 cigarettes a day had an odds ratio of $2.2(95 \% \mathrm{CI}$ 1.1 ; 4.6) compared to women who had never smoked. Former use of the contraceptive pill resulted in a $2.3(95 \%$ CI $1.1 ; 4.6)$ times higher prescription rate of HRT within the 9 months compared to women who never used the pill.

\subsection{Determinants of first HRT for women with and without typical complaints}

In the multivariate analyses (Table 2 ) all relationships between determinants and HRT prescription appeared to be modified by the presence of typical complaints. For women without typical complaints the ISH and the former use of the contraceptive pill were determinants of initial HRT prescription. Women above the median of the ISH had a $5.5(95 \%$ CI $1.9 ; 15.5)$ higher rate of HRT than women below the median, while for former users of the contraceptive pill the odds ratio was $4.6(95 \%$ CI $1.0 ; 20.5)$.

For the women with typical complaints the attitude cluster 'menopause should be treated' was related to HRT prescription. Women who thought more positively about treatment had an odds ratio 
of $3.8(95 \%$ CI $1.8 ; 8.0)$ compared to women who thought more negatively.

\section{Discussion}

In this follow-up study of 1689 women aged 45-60 years in an open population, the 9 month cumulative incidence of first hormonal replacement therapy prescriptions was $6.2 \%$. When the independent effects of several determinants were studied by means of a logistic regression analysis this incidence appeared to be higher for women (i) with typical complaints, (ii) with a lower level of well-being as measured by the ISH, (iii) with a more positive attitude towards 'the menopause should be treated', (iv) smoking more than 15 cigarettes a day and (v) who formerly used the contraceptive pill.

In this 9 month study a cumulative incidence of $6.2 \%$ of first HRT was established, whereas the prevalence of HRT use at baseline was $11.5 \%$. This implies that either the prevalence of HRT is rapidly increasing or that many women stop taking HRT. We were able to verify these options at the two pharmacies where the women were still registered. The pharmacies reported that one year and 9 months after the questionnaire 68 of the 103 $(66 \%)$ women were no longer prescribed HRT (one woman moved). Therefore, the problem of a low prevalence of HRT as stated by several studies $[8,9,15]$ might be attributed to the problem of continuating rather than starting HRT.

Several determinants of HRT prescription that have been found in our study are in line with previous findings. An association between general well-being and HRT has not been reported as a determinant of HRT in other studies. However, these studies were cross-sectional and therefore the level of well-being may already have been influenced by HRT $[14,15]$. The relationship between attitude towards treatment and HRT has been found before [27]. Apparently, the belief in the efficacy of medical treatment of the menopause is at least as important as the presence of typical complaints. The relationship between smoking behaviour and HRT was ascertained in one study [28], but absent in another study [15]. Perhaps women who smoke may therefore experience typical complaints more intensely. In several earlier studies, the former use of the contraceptive pill was a determinant of HRT use [15]. Probably, once a woman has decided to use hormones with a contraceptive purpose, she has less fear of cancer and other adverse effects.

In our study, hysterectomy was, in contrast to other studies [15,29], a determinant in the univariate analysis only. Once well-being, smoking behaviour and/or former use of the pill were taken into account by means of the logistic regression analysis, the prediction of HRT prescription did not depend on hysterectomy. The same was found for the SIP emotions, feelings and sensations, the menopausal status according to the woman, age and general practice.

The cumulative incidence for women with typical (climacteric) complaints was $8.0 \%$ versus $4.4 \%$ for women without typical complaints. Hence, for the majority of the women a therapeutic indication existed. For women without and with typical complaints it appears that the prediction of HRT use is determined by different factors, i.e. a lower level of well-being and the former use of the contraceptive pill for women without these complaints and a positive attitude towards 'menopause should be treated' for women with these complaints.

It is remarkable that a lower level of well-being as measured by the ISH determined HRT prescription (odds ratio $=5.5$ ) for women without typical complaints. As yet, no clear views exist about the beneficial effect of HRT on well-being in the $a b$ sence of typical symptoms. From this we may tentatively conclude that a low level of well-being as measured by the ISH may influence the woman and/or her physician in the process leading to HRT prescription. In a study of Hunt a considerable influence of patient's demand on HRT prescription was apparent (21\% of all prescriptions) [19]. This conclusion is also supported by the divergence in HRT prescription rates between the general practices, especially for women without typical complaints. Ferguson also observed differences between physicians in HRT prescription [27]. When typical complaints are present, the prescription of HRT mainly depends on the woman's attitude towards 'menopause 
should be treated' and not on her experienced level of well-being.

To our knowledge this is the first study to assess the cumulative incidence of HRT and its determinants in an unselected population. By gathering the data from the pharmacists, neither the women's nor the doctor's attention was drawn to HRT prescription. The information about HRT provided in the last part of the questionnaire might have influenced the incidence of HRT in the first few months after the filling out of the questionnaire. However, we did not find such an increase in the prescription. Another limitation of this study is the possibility of a change in typical complaints during the 9 month follow-up. Women were categorized as women with or without typical complaints according to the presence of these symptoms at the time of the questionnaire. Subsequent changes in the experience of these complaints, which were not measured, may have been of influence on the prescription of HRT. Most likely this resulted in an under-estimation of the relationships reported in the separate analyses. Another limitation is the fact that we measured delivery of HRT prescriptions and not the actual use. Moreover, some women might have incidentally filled HRT prescriptions in other pharmacies than the two present in Krimpen aan den IJssel. As there is a considerable distance to other pharmacies and only 31 out of 1947 women could not be traced at either pharmacy this will only have happened in few cases. Nevertheless a slight underestimation of the cumulative incidence of HRT may be present. Finally, although we evaluated most variables known to possibly influence the prescription of HRT, some other factors such as those related to the physician were not measured.

It may be concluded that the cumulative incidence of first HRT prescription is high, but that the majority of the women stop taking HRT within 2 years, which implies that most indications are rather therapeutic than preventive. When typical complaints are absent, women with a level of well-being above the median are prescribed HRT five times more frequently. The question arises whether for these women the indication is therapeutic, preventive or equivocal. For women with typical complaints the doctor's prescription is primarily related to the woman's attitude towards (medical) treatment of the menopause. The process of decision-making about starting and continuation of HRT is complex, depending on a variety of determinants modified by the presence of the typical climacteric complaints. Insight of this process may contribute to a more rational prescription of HRT.

\section{Acknowledgements}

This work was supported by grants from CibaGeigy, Schering and Wyeth-Ayerst. We thank Mrs. De Haan-Meynell for her helpful comments. Furthermore, we appreciate the assistance of the pharmacists B.A.J. Geurts and P.K. Schot.

\section{References}

[1] Greenblatt RB, Barfield WE, Garner JF, Calk GL, Harrod JP. Evaluation of estrogen, androgen, estrogenandrogen combination and placebo in treatment of menopause. J Clin Endocrinol Metab 1950; 10: 154-158.

[2] Riggs BL, Melton LJ III. The prevention and treatment of osteoporosis. N Engl J Med 1992; 327: 620-627.

[3] Kanis JA, Johnell O, Gullberg B, Allander E, Dilsen G, Gennari $\mathrm{K}$ et al. Evidence for efficacy of drugs affecting bone metabolism in preventing hip fracture. Br Med J 1992; 305: 1124-1128.

[4] Consensus development conference. A prophylaxis and treatment of osteoporosis. Am J Med 1991; 90: 107-110.

[5] Barrett-Connor E, Bush TL. Estrogen and coronary heart disease in women. JAMA 1991; 265: 1861-1867.

[6] Stampfer MJ, Colditz GA. Postmenopausal estrogens and coronary heart disease: a review of epidemiologic evidence and a meta-analysis. Prev Med 1991; 20: 47-63.

[7] Harlap S. The benefits and risks of hormone replacement therapy: an epidemiologic overview. Am J Obstet Gynecol 1992; 166: 1986-1992.

[8] Oddens BJ, Boulet MJ, Lehert P, Visser AP. Has the climacteric been medicalized? A study on the use of medication for climacteric complaints in four countries. Maturitas 1992; 15: 171-180.

[9] Cauley JA, Cummings SR, Black DM, Mascioli SR, Seeley DG. Prevalence and determinants of estrogen replacement therapy in elderly women. Am J Obstet Gynecol 1990; 163: 1438-1444.

[10] Wren BG, Brown L. Compliance with hormonal replacement therapy. Maturitas 1991; 13: 17-21.

[11] Draper J, Roland M. Perimenopausal women's views on taking hormone replacement therapy to prevent osteoporosis. Br Med J 1990; 300: 786-788.

[12] Hahn RG. Compliance considerations with estrogen re- 
placement therapy: withdrawal bleeding and other factors. Am J Obstet Gynccol 1989; 161: 1854-1858.

[13] Barret-Connor E. Postmenopausal estrogen and prevention bias. Ann Intern Med 1991; 115: 455-456.

[14] Schmitt N, Gogate J, Rothert M, Rovner D, Holmes M, Talarcyzk G, Given B, Kroll J. Capturing and clustering women's judgment policies: the case of hormonal therapy for menopause. J Gerontol 1991; 46: 92-101.

[15] Ringa V, Ledésert B, Gueguen R, Schiele F, Breart G. Determinants of hormonal replacement therapy in recently postmenopausal women. Eur J Obst Gynaecol R B 1992; 45: 193-200.

[16] Holzman GB, Ravitch MM, Metheney W, Rothert ML, Holmes M, Hoppe RB. Physicians' judgment about estrogen replacement therapy for menopausal women. Obstet Gynecol 1984; 63: 303-311.

[17] Bryce FC, Lilford RJ. General practitioners use of hormone replacement therapy in Yorkshire. Eur $\mathbf{J}$ Obstet Gyn R B 1990; 37: 55-61.

[18] Roberts PJ. The menopause and hormone replacement therapy: views of women in general practice receiving hormone replacement therapy. Br J Gen Pract 1991; 41 : 421-424.

[19] Hunt K. Perceived value of treatment among a group of long-term users of hormone replacement therapy. J R Coll Gen Pract 1988; 38: 398-401.

[20] Groeneveld FPMJ, Bareman FP, Barentsen R, Dokter $\mathrm{HJ}$, Drogendijk AC, Hoes AW. The climacteric and wellbeing. J Psychosom Obst Gyn 1993; 14: 127-143.

[21] Groeneveld FPMJ, Bareman FP, Barentsen R, Hoes
AW, Dokter HJ, Drogendijk AC. Relationships between attitude towards menopause, well-being and medical attention, among women aged $45-60$ years. Maturitas 1993; 17: 77-88.

[22] Visser $\mathrm{APh}$. De betekenis van de VOEG: enkele gegevens over begripsvaliditeit. Gezondheid \& Samenleving 1983; 4: $177-188$

[23] Van Reek J, Diederiks J, Van Zutphen W, Seelen A. Subjective complaints and blood pressure. J Psychosom Res 1982; 26: 155-165.

[24] Joosten J, Drop MJ. De betrouwbaarheid en de vergelijkbaarheid van de drie versies van de VOEG. Gezondheid \& Samenleving 1987; 8: 251-252.

[25] Pollard WE, Bobbit RA, Bergner M, Martin DP, Gilson MA and BS. The Sickness Impact Profile: reliability of a health status measure. Med Care 1976; 14: 146-155.

[26] Jacobs HM, Luttik A, Touw-Otten FWMM, De Melker RA. De 'Sickness Impact Profile'; resultaten van een valideringsonderzoek van de Nederlandse versie. Ned Tijdschr Geneesk 1990; 134: 1950-1954.

[27] Ferguson KJ, Hoegh C, Johnson S. Estrogen replacement therapy: a survey of women's knowledge and attitudes. Arch Intern Med 1989; 149: 133-136.

[28] Greenberg G, Thompson SG, Meade TW. Relation between cigarette smoking and use of hormonal replacement therapy for menopausal symptoms. J Epidemiol Community Health 1987; 41: 26-29.

[29] Pedersen SH, Jeune B. Prevalence of hormone replacement therapy in a sample of middle-aged women. Maturitas 1988; 9: 339-345. 